University of Nebraska - Lincoln

DigitalCommons@University of Nebraska - Lincoln

Faculty Publications: Department of Entomology

4-1986

Integration of Host Plant Resistance and Insecticides in the Control of Nephotettix virescens (Homoptera: Cicadelli-dae), a Vector of Rice Tungro Virus
E. A. Heinrichs
H. R. Rapusas
G. B. Aquino
F. Palis

Follow this and additional works at: https://digitalcommons.unl.edu/entomologyfacpub

Part of the Agriculture Commons, and the Entomology Commons

This Article is brought to you for free and open access by the Entomology, Department of at

DigitalCommons@University of Nebraska - Lincoln. It has been accepted for inclusion in Faculty Publications:

Department of Entomology by an authorized administrator of DigitalCommons@University of Nebraska - Lincoln. 
Published in Journal of Economic Entomology 79:2 (April 1986), pp. 437-443; doi: 10.1093/jee/79.2.437 Copyright (C) 1986 Entomological Society of America; published by Oxford University Press. Used by permission.

Submitted July 27, 1985; accepted November 1, 1985; published April 1, 1986.

\title{
Integration of Host Plant Resistance and Insecticides in the Control of Nephotettix virescens (Homoptera: Cicadellidae), a Vector of Rice Tungro Virus
}

\author{
E. A. Heinrichs, H. R. Rapusas, G. B. Aquino, and F. Palis
}

International Rice Research Institute, Manila, Philippines

Current address of E. A. Heinrichs: Department of Entomology, Louisiana State University Agricultural Center, 402 Life Sciences Building, Baton Rouge, LA 70803-1710

\begin{abstract}
Combined effects of levels of vector resistance and insecticide application in control of rice tungro virus (RTV) were determined in three field tests. Cultivar "IR28," with high levels of resistance to the vector, Nephotettix virescens (Distant), had low RTV infection in all treatments including the untreated check. In moderately resistant "IR36," RTV decreased with an increase in level of insecticide but did not decrease to a level equaling the untreated "IR28." The N. virescens-susceptible cultivar "IR22" had extremely high levels of RTV infection at all insecticide levels. Economic analysis indicated that gross profit and net gain were highest in the N. virescens-resistant "IR28," intermediate in moderately resistant "IR36," and lowest in susceptible "IR22."
\end{abstract}

Among the Nephotettix species occurring in rice in South and Southeast Asia, N. virescens (Distant) is the most important. N. virescens removes plant sap from the xylem and phloem but seldom reaches population levels that cause direct damage. However, it is an important pest because it is an efficient vector of rice tungro virus (RTV) (Ling 1975). RTV has caused severe yield losses in South and Southeast Asia in the last two decades. Outbreaks were reported in the Philippines during 1970 to 1972 and again in 1983. In 1966, 660,000 ha of rice were damaged in Thailand (Lamey et al. 1967). Yield losses are most 
severe when infection occurs early in the crop season and losses decrease when plants are older (Ling and Palomar 1966).

$N$. virescens-resistant cultivars have been released to control RTV, but they are not resistant to the virus. Of the 27 commercial cultivars developed at the International Rice Research Institute (IRRI), all but one are resistant or moderately resistant to $N$. virescens (Heinrichs et al. 1982). The two most widely grown cultivars in Asia, "IR36" and "IR42," are moderately resistant; when RTV pressure is high, percentage of RTV-infected plants can reach $80 \%$ (Rapusas and Heinrichs 1982). Thus, the application of insecticides needs to be integrated with the moderate resistance to $N$. virescens when viruliferous vector populations are high. An early warning system for RTV based on the number and percentage of viruliferous vectors in a population has been developed (IRRI 1984). Based on this information, a decision can be made as to the need for prophylactic applications of insecticides to protect the rice crop from RTV. Here we report the effects of combinations of host plant resistance and insecticides on $N$. virescens populations, subsequent RTV infection and grain yields, and the economics of the various combinations.

\section{Materials and Methods}

Two tests were conducted simultaneously during the wet season of 1983. One was done in a farmer's field in Victoria, Laguna (near IRRI), another at the IRRI farm, and the third during the dry season of 1984 in Victoria.

Rice cultivars used were "IR22" (susceptible to N. virescens), "IR36" (moderately resistant), and "IR28" (resistant) (Heinrichs et al. 1982). The yield of the three cultivars in the absence of biological stresses is similar. Plot size at Victoria was 5 by $6 \mathrm{~m}$ and 3.5 by $5.0 \mathrm{~m}$ at IRRI. In all the experiments, standard agronomic practices for land preparation were followed. Twenty-day-old seedlings of the test cultivars were transplanted at a spacing of 25 by $25 \mathrm{~cm}$ in field plots separated by levees. In all tests the experimental design consisted of a split plot with cultivar as the main plot and insecticide treatments as subplots. Each treatment was replicated four times.

\section{Test 1 (IRRI, 1983 Wet Season)}

Nitrogen at $30 \mathrm{~kg}(\mathrm{AI}) / \mathrm{ha}$ was incorporated into the soil at the last harrowing before transplanting and broadcast on the surface at 45 days after transplanting (DT). The herbicide butachlor was broadcast at $1 \mathrm{~kg}(\mathrm{AI}) / \mathrm{ha}$ at $3 \mathrm{DT}$ and plots were weeded by hand at $30 \mathrm{DT}$. Diazinon granules were broadcast into the paddy water at $1.5 \mathrm{~kg}(\mathrm{AI}) / \mathrm{ha}$ at different frequencies. Treatments consisted of an application at 1 DT; 1 and 11 DT; 1, 11, and 21 DT; 1, 11, 21, and 31 DT; and an untreated control.

To determine the efficacy of the insecticides, 10 pairs (male and female) of nonviruliferous $N$. virescens adults were caged on one hill of each plot and mortality was observed 48 $\mathrm{h}$ after caging. Live hoppers were released from the cage after counting. Caging of hoppers was done at 5-day intervals from 1 DT to 40 DT.

$N$. virescens populations in each plot were monitored by taking 10 sweep net samples per plot at weekly intervals from 14 DT to 47 DT. To insure the occurrence of RTV infection, 20 viruliferous $N$. virescens adults were released in each plot at 10 DT to start the virus 
infection. RTV-infected plants from each plot (excluding the two outer rows) were counted at $60 \mathrm{DT}$ and percentage of RTV infection computed.

Yield data were obtained from a $10-\mathrm{m}^{2}$ area of each plot. The gross profit and net gain from the use of the insecticide were computed. Net gain was computed by subtracting the cost of insecticide application from the gross profit. Data were subjected to an analysis of variance and treatment means were separated $(P=0.05$; Duncan's [1951] multiple range test).

\section{Test 2 (Victoria, 1983 Wet Season)}

NPK fertilizer was applied at the rate of $90-30-30 \mathrm{~kg} / \mathrm{ha}$. N was applied twice: by incorporation into the soil at transplanting and at $45 \mathrm{DT}$. P and $\mathrm{K}$ were applied once only before transplanting. Butachlor (1 kg [AI]/ha) was broadcast at $3 \mathrm{DT}$ and plots were weeded by hand at 30 DT. Carbofuran granules at $0.0,1.0,1.5$, and $2.0 \mathrm{~kg}(\mathrm{AI}) / \mathrm{ha}$ were incorporated into the soil at the last harrowing (1 day before transplanting). In assessing the efficiency of the insecticide, the N. virescens population and RTV infection were determined according to the procedure described in test 1 except that sweep net counts were taken at weekly intervals from 14 DT to 42 DT. Yield data were gathered, and the economics of the various treatments were computed and data statistically analyzed as in test 1 .

\section{Test 3 (Victoria, 1984 Dry Season)}

NPK fertilizer was applied at the rate of $120-30-30 \mathrm{~kg} / \mathrm{ha} . \mathrm{N}$ was applied three times: at transplanting, at $45 \mathrm{DT}$, and at $60 \mathrm{DT}$. P and K were applied just before transplanting. Butachlor was applied at $3 \mathrm{DT}$ as a spray at $0.75 \mathrm{~kg}$ (AI) in 300 liters water per ha. Plots were also weeded by hand at 30 DT. Carbofuran granules were incorporated into the soil at the last harrowing ( 1 day before transplanting) at $0.0,0.25,0.5,0.75$, and $1.0 \mathrm{~kg}(\mathrm{AI}) / \mathrm{ha}$. To increase RTV infection, seedlings of "TN1," a N. virescens- and RTV-susceptible cultivar, were planted as borders 5 days before transplanting of the test cultivars. Releases of viruliferous $N$. virescens were made at 7-day intervals until ca. $80 \%$ of the "TNl" plants were infected. Test plants were counted at $60 \mathrm{DT}$ and percentage RTV infection computed. $N$. virescens populations were determined and other data collected as described for the other two tests. All the other data were gathered and statistical analyses conducted as described in the other tests.

\section{Results}

Test 1 (IRRI, 1983 Wet Season)

Based on the average of the mortality readings taken on caged N. virescens from 1 to $40 \mathrm{DT}$, mortality was highest on "IR28" (Fig. 1A). As the number of insecticide applications increased from 0 to 4, mortality increased in a linear fashion. Mortality on "IR36" and "IR22" was similar in the check, but there was a steeper increase in mortality as the number of applications on "IR36" increased as compared with "IR22." 

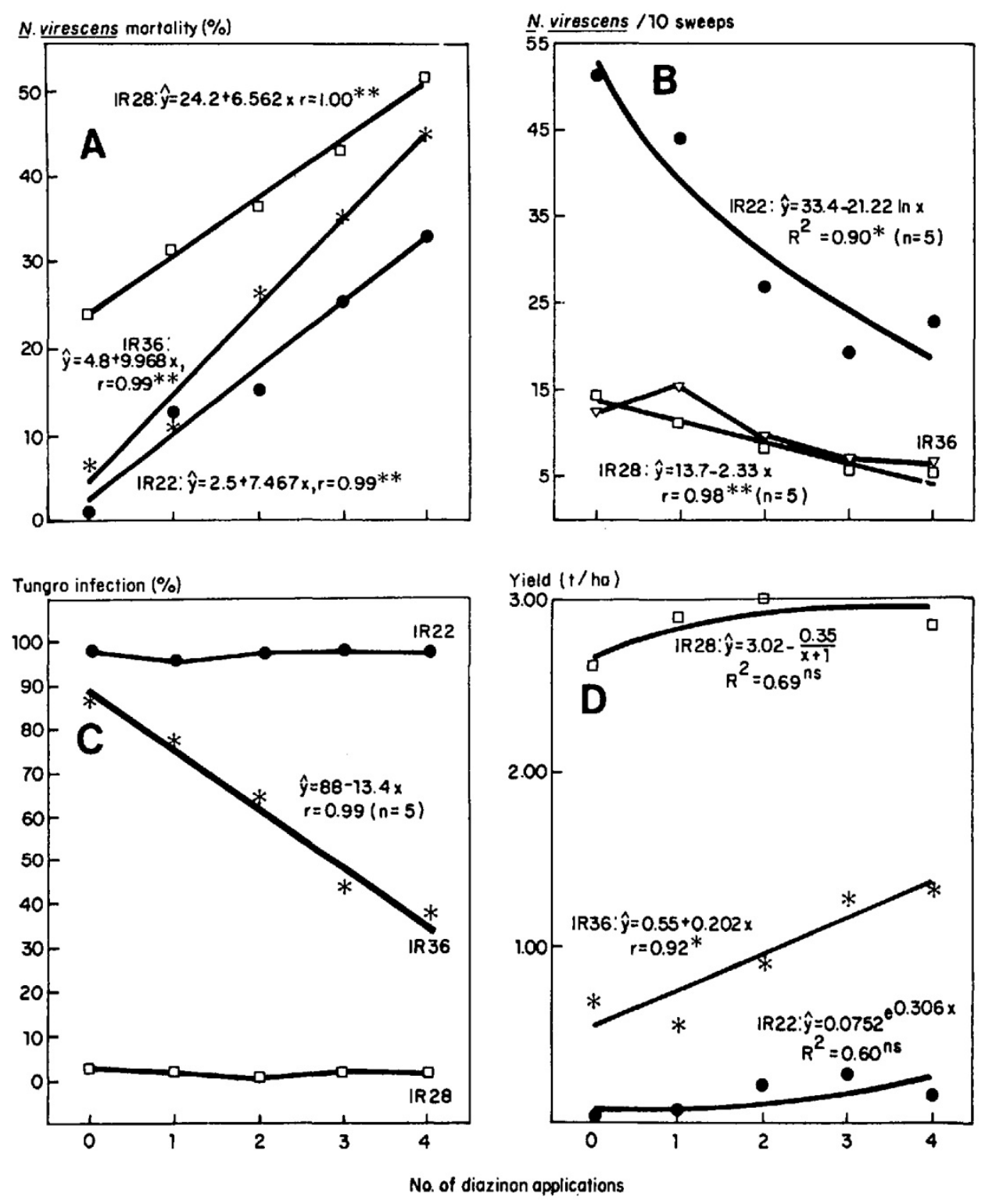

Figure 1. N. virescens mortality and field populations, RTV infection, and grain yields as affected by number of diazinon applications at $1.5 \mathrm{~kg}(\mathrm{AI}) / \mathrm{ha}$ on rice cultivars "IR22," "IR28," and "IR36" having different levels of N. virescens resistance, IRRI, 1983 wet season.

(A) Mortality of caged N. virescens. (B) N. virescens populations per 10 sweeps at 35 DT.

(C) Percent RTV infection. (D) Grain yield.

Natural N. virescens populations at 35 DT were highest in "IR22." They reached 52 per 10 sweeps in the check and decreased to 23 per 10 sweeps with four insecticide applications; the last application was made at 31 DT (Fig. 1B). Populations on "IR36" and "IR28" were similar in all treatments; they decreased slightly with an increase in the number of 
applications from 15 in the check to 6 per 10 sweeps with four applications. RTV infection was almost 100\% in all treatments of "IR22" (Fig. 1C). In "IR36," RTV infection was $88 \%$ in the check and linearly decreased to $40 \%$ with four applications. RTV infection was $<5 \%$ on all treatments of "IR28."

Yield was related to degree of RTV infection in the various treatments (Fig. 1D). Yield was about $3 \mathrm{t} / \mathrm{ha}$ in all "IR28" treatments. In "IR36," yield increased slightly as the number of insecticide applications increased. Yield was $0.7 \mathrm{t} / \mathrm{ha}$ in the check and $1.3 \mathrm{t} / \mathrm{ha}$ with four applications. There was a slight increase in the yield of "IR22" with an increased number of insecticide applications; however, maximum yield with three applications was only 0.3 t/ha.

Gross profit of the various treatments was highest in "IR28" (Table 1). Because of low yields, gross profit in "IR22" was extremely low (\$9-\$42/ha). Profit was $\$ 100-\$ 200$ in "IR36" and more than $\$ 400$ in "IR28." After subtracting the cost of insecticide application from the gross profit, there was a loss in net gain of $-\$ 6$ to $-\$ 55$ in "IR22" because the increase in gross profit with insecticide was less than the cost of the insecticide. There was a positive net gain of about \$100 in "IR36" and \$400 in "IR28." However, there was no significant increase in net gain by applying one or more insecticide applications in either "IR36" or "IR28." Gain from insecticide was zero or negative in most cases. Gain was positive but low at three and four applications on "IR36" and one and two applications on "IR28." The benefit:cost ratios for insecticide were $<1$ in all treatments. 
Table 1. Yield and economics ${ }^{\mathrm{a}}$ of different numbers of diazinon applications on $N$. virescens-susceptible ("IR22"), moderately resistant ("IR36"), and resistant ("IR28") cultivars, IRRI, 1983 wet season

\begin{tabular}{|c|c|c|c|c|c|c|}
\hline $\begin{array}{c}\text { Diazinon } \\
\text { applications } \\
(\text { no. })^{b}\end{array}$ & $\begin{array}{c}\text { Grain yield } \\
(\mathrm{t} / \mathrm{ha})\end{array}$ & $\begin{array}{c}\text { Gross profitc } \\
(\$)\end{array}$ & $\begin{array}{c}\text { Cost of } \\
\text { insecticide } \\
\text { application }\end{array}$ & $\begin{array}{c}\text { Net gain } \\
(\$)^{\mathrm{e}}\end{array}$ & $\begin{array}{c}\text { Gain from } \\
\text { insecticide }^{f} \\
(\%)\end{array}$ & Benefit:cost 8 \\
\hline \multicolumn{7}{|l|}{ "IR22" } \\
\hline 0 & $0.06 a$ & $9 a(c)$ & 0 & $9 a$ & - & - \\
\hline 1 & $0.09 a$ & $14 \mathrm{a}(\mathrm{c})$ & 20 & $-6 a b$ & 0 & $<1$ \\
\hline 2 & $0.22 \mathrm{a}$ & $35 a(c)$ & 40 & $-5 a b$ & 0 & $<1$ \\
\hline 3 & $0.27 \mathrm{a}$ & $42 \mathrm{a}(\mathrm{c})$ & 60 & $-18 \mathrm{ab}$ & 0 & $<1$ \\
\hline 4 & $0.16 a$ & $25 a(c)$ & 80 & $-55 b$ & 0 & $<1$ \\
\hline \multicolumn{7}{|l|}{ "IR36" } \\
\hline 0 & $0.69 b c$ & $108 \mathrm{bc}(\mathrm{b})$ & 0 & $108 \mathrm{ab}$ & - & - \\
\hline 1 & $0.55 \mathrm{c}$ & $86 c(b)$ & 20 & $66 \mathrm{~b}$ & -42 & $<1$ \\
\hline 2 & $0.91 b$ & $143 b(b)$ & 40 & $103 a b$ & -5 & $<1$ \\
\hline 3 & $1.27 \mathrm{a}$ & $199 a(b)$ & 60 & $139 a$ & 31 & $<1$ \\
\hline 4 & $1.34 \mathrm{a}$ & $210 a(b)$ & 80 & $130 a$ & 22 & $<1$ \\
\hline \multicolumn{7}{|l|}{ "IR28" } \\
\hline 0 & $2.64 b$ & $415 b(a)$ & 0 & $415 a$ & - & - \\
\hline 1 & $2.88 \mathrm{ab}$ & $452 \mathrm{ab}(\mathrm{a})$ & 20 & $432 a$ & 17 & $<1$ \\
\hline 2 & $3.00 \mathrm{a}$ & $471 \mathrm{a}(\mathrm{a})$ & 40 & $431 a$ & 16 & $<1$ \\
\hline 3 & $2.94 \mathrm{ab}$ & $462 \mathrm{ab}(\mathrm{a})$ & 60 & $402 \mathrm{ab}$ & -13 & $<1$ \\
\hline 4 & $2.88 \mathrm{ab}$ & $452 \mathrm{ab}(\mathrm{a})$ & 80 & $372 b$ & -43 & $<1$ \\
\hline
\end{tabular}

In a column, means followed by the same letter within each cultivar and among cultivars with the same number of applications (in parentheses for gross profit) are not significantly different $(P>0.05$; Duncan's [1951] multiple range test).

a. Based on an exchange rate of 14 Philippine pesos/US\$1 in December 1983.

b. Granules broadcast at $1.5 \mathrm{~kg}$ (AI)/ha. One application was made at $1 \mathrm{DT}$, two applications at 1 and $11 \mathrm{DT}$, three at 1, 11, and 21 DT, and four at 1, 11, 21, and 31 DT.

c. Based on a rough rice price of US\$157/t.

d. Cost of insecticide + labor.

e. Gross profit - cost of insecticide application.

f. Net gain of treatment - net gain of control.

g. Gain from insecticide $\div$ cost of insecticide application.

\section{Test 2 (Victoria, 1983 Wet Season)}

$N$. virescens mortality in soil-incorporated carbofuran treatments is presented as an average of the three application rates because differences in mortality among rates were not significant. In "IR22" mortality reached $62 \%$ at 27 DT and decreased to 5\% at 43 DT (Fig. 2). Mortality in the untreated plots ranged from 0 to $18 \%$. Mortality in "IR36" was generally $10-15 \%$ higher in all treatments than that of "IR22." In "IR28," mortality reached a peak of $80 \%$ at 27 DT and was still $55 \%$ at 43 DT. Because of the effect of level of $N$. virescens resistance, mortality (averaging ca. 30\%) in the untreated plots of "IR28" was higher than in "IR22" and "IR36." 


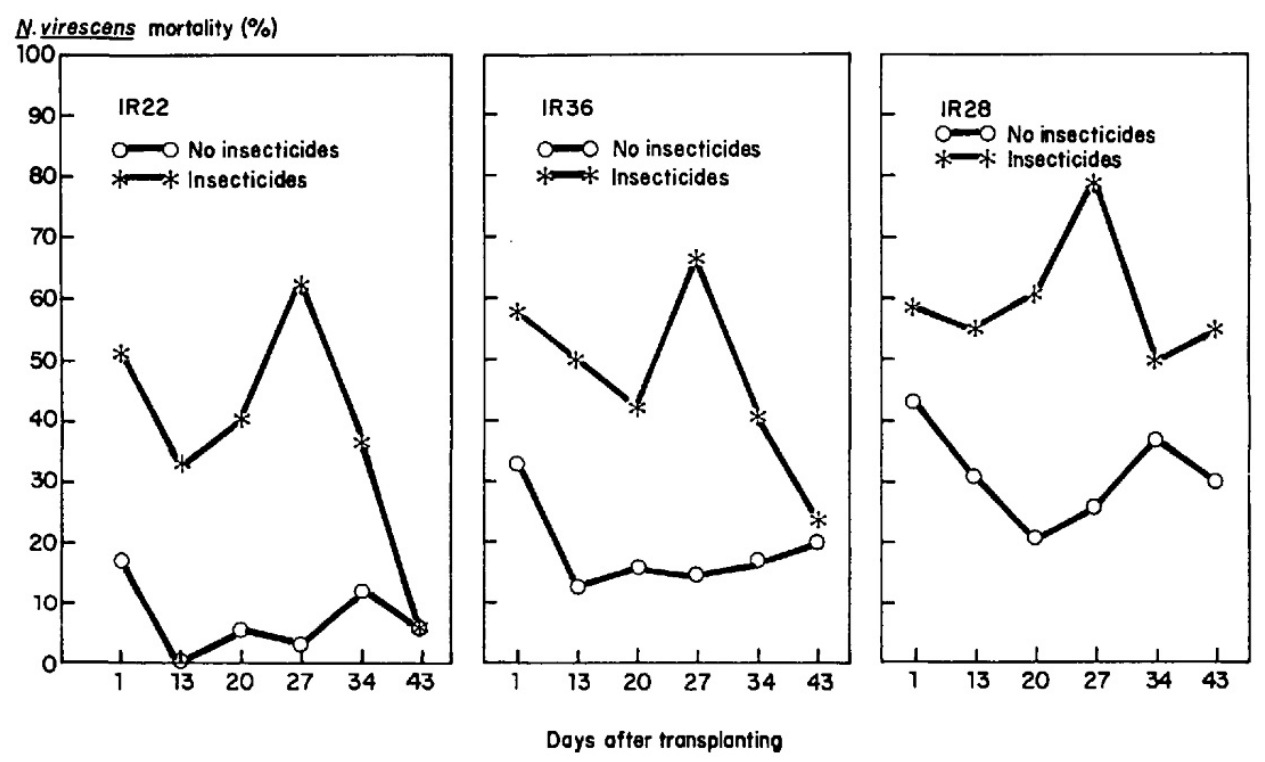

Figure 2. Mortality of caged $N$. virescens as affected by levels of $N$. virescens resistance in rice cultivars and soil incorporation of carbofuran granules. Insecticide data are based on a mean of three rates: 1.0, 1.5, and $2.0 \mathrm{~kg}(\mathrm{AI}) /$ ha, Victoria, Laguna, 1983 wet season.

RTV decreased from almost $98 \%$ in the "IR22" check to $58 \%$ at $1.5 \mathrm{~kg}$ (AI) carbofuran/ha and again increased to $70 \%$ at $2.0 \mathrm{~kg}(\mathrm{AI}) / \mathrm{ha}$, but there was no significant difference between the 1.5 and $2.0 \mathrm{~kg}(\mathrm{AI}) / \mathrm{ha}$ rates (Fig. 3A). RTV infection in "IR28" was $0 \%$ at the three rates and averaged $2 \%$ in the check. 

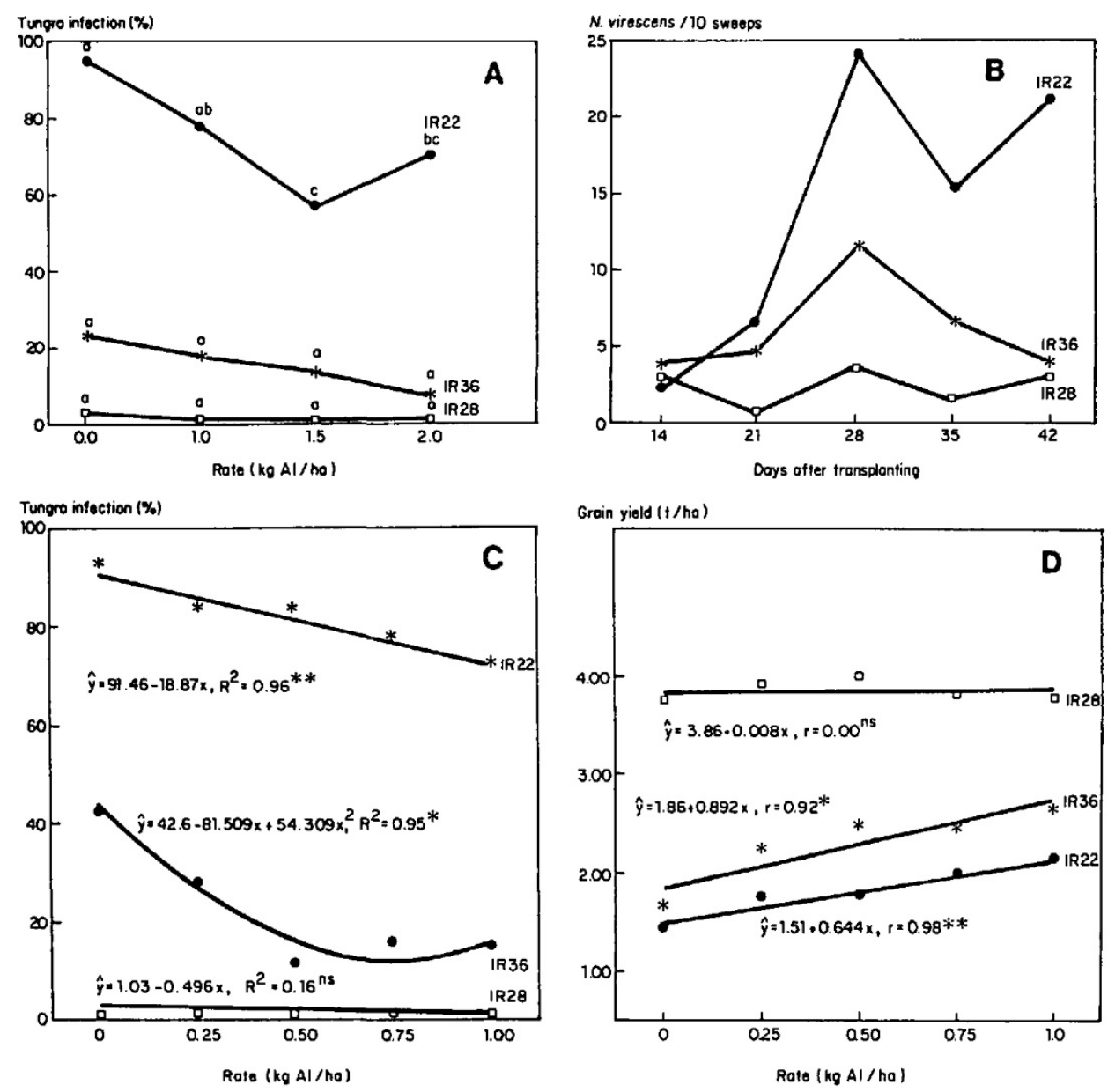

Figure 3. Percent RTV infection, $N$. virescens populations, and grain yield of rice cultivars "IR22," "IR28," and "IR36" having different levels of N. virescens resistance as affected by rates of soil-incorporated carbofuran. (A) Percent RTV infection, Victoria, Laguna, 1983 wet season. For each cultivar, insecticide rates with the same letter are not significantly different ( $P=0.05$ level; Duncan's [1951] multiple range test). (B) N. virescens populations per 10 sweeps, Victoria, Laguna, 1984 dry season. Data for soil-incorporated carbofuran rates $(0,0.25,0.50,0.75$, and $1.00 \mathrm{~kg}[\mathrm{AI}] / \mathrm{ha})$ were pooled and averaged across treatments. (C) Percent RTV infection, Victoria, Laguna, 1984 dry season. (D) Grain yield, Victoria, Laguna, 1984 dry season.

Yields among insecticide rates on either "IR28" or "IR36" ranging between 2.4 to $2.9 \mathrm{t} / \mathrm{ha}$ (Table 2) did not differ significantly. Yields of "IR22" treatments were related to degree of RTV infection, with yield significantly higher at $1.5 \mathrm{~kg}$ than at $2.0 \mathrm{~kg}(\mathrm{AI}) / \mathrm{ha}$.

Gross profit and net gain were similar at the 1.5-kg rate in "IR22" and all rates in "IR36" and "IR28" (Table 2). Net gain was highest in "IR36" and "IR28." Yields among the rates did not differ significantly. 
Gain from insecticide was highest in the $1.5-\mathrm{kg}$ "IR22" treatment. Because the insecticide did not increase yields in the "IR36" and "IR28" treatments, gain from insecticide was low or negative and benefit:cost ratios usually $<1$. In contrast, the benefit:cost ratio for the 1.5$\mathrm{kg}$ "IR22" treatment was 4.

Table 2. Benefit:cost analysis of varying levels of host plant resistance as affected by four rates of soilincorporated carbofuran, Victoria, Laguna, 1983 wet season

\begin{tabular}{|c|c|c|c|c|c|c|}
\hline $\begin{array}{l}\text { Carbofuran } \\
\text { (kg [AI]/ha) }\end{array}$ & $\begin{array}{c}\text { Grain yield } \\
\text { (t/ha) }\end{array}$ & $\begin{array}{c}\text { Gross profitc } \\
(\mathrm{US} \$ / \mathrm{ha})^{\mathrm{a}}\end{array}$ & $\begin{array}{l}\text { Insecticide } \\
\text { application } \\
\text { (US\$/ha) }\end{array}$ & $\begin{array}{l}\text { Net gain } \\
\text { (US\$/ha) }\end{array}$ & $\begin{array}{l}\text { Gain from } \\
\text { insecticide } \\
(\mathrm{US} \$ / \mathrm{ha})^{\mathrm{d}}\end{array}$ & $\begin{array}{c}\text { Benefit:cost } \\
\text { ratio }^{\text {e }}\end{array}$ \\
\hline \multicolumn{7}{|l|}{ "IR22" } \\
\hline 0.0 & $1.0 \mathrm{c}$ & $153 c(b)$ & 0 & $153 b$ & - & - \\
\hline 1.0 & $1.6 \mathrm{~b}$ & $241 b(b)$ & 26 & $215 b$ & 62 & 2.4 \\
\hline 1.5 & $2.4 a$ & $356 a(a)$ & 39 & $317 a$ & 164 & 4.2 \\
\hline 2.0 & $1.8 \mathrm{~b}$ & $165 b(a)$ & 51 & $214 b$ & 61 & 1.2 \\
\hline \multicolumn{7}{|l|}{ "IR36" } \\
\hline 0.0 & $2.4 a$ & $357 a(a)$ & 0 & $357 a$ & - & - \\
\hline 1.0 & $2.6 a$ & $385 a(a)$ & 26 & $359 a$ & 2 & $<1$ \\
\hline 1.5 & $2.6 a$ & $387 a(a)$ & 39 & $348 a$ & -9 & $<1$ \\
\hline 2.0 & $2.6 a$ & $383 a(a)$ & 51 & $332 a$ & -25 & $<1$ \\
\hline \multicolumn{7}{|l|}{ “IR28" } \\
\hline 0.0 & $2.5 a$ & $375 a(a)$ & 0 & $375 a$ & - & - \\
\hline 1.0 & $2.9 \mathrm{a}$ & $430 \mathrm{a}(\mathrm{a})$ & 26 & $404 a$ & 29 & 1.1 \\
\hline 1.5 & $2.7 \mathrm{a}$ & $404 a(a)$ & 39 & $365 a$ & -10 & $<1$ \\
\hline 2.0 & $2.6 a$ & $382 a(a)$ & 51 & $331 a$ & -44 & $<1$ \\
\hline
\end{tabular}

In a column, means followed by a common letter within each cultivar and among cultivars with the same rate (in parentheses for gross profit) are not significantly different $(P>0.05$; Duncan's [1951] multiple range test).

a. Based on a rough price of US\$157/t. Exchange rate $=14$ Philippine pesos/US $\$ 1$.

b. Carbofuran (Furadan $3 \mathrm{G}$ ) at US $\$ 12.12$ per $16.7 \mathrm{~kg}$ per bag and labor cost per hectare of US $\$ 2$ per $8 \mathrm{~h}$ for broadcasting granules.

c. Gross profit - cost of insecticide application.

d. Net gain of treatment - net gain of control.

e. Gain from insecticide $\div$ cost of insecticide application.

\section{Test 3 (Victoria, 1984 Dry Season)}

$N$. virescens populations for all insecticide treatments of each cultivar were similar; therefore, the data were pooled and averaged across treatments. Populations were similar for the three cultivars at 14 DT but later increased to 24 per 10 sweeps in "IR22" and 12 in "IR36" at 28 DT (Fig. 3B). Populations on "IR28" remained low throughout the sampling period; they fluctuated between 0 and 3 per 10 sweeps.

RTV infection was again highest in "IR22," intermediate in "IR36," and lowest in "IR28" (Fig. 3C). There was a rate effect in "IR22" and "IR36." There was a decrease from 95\% infection in the "IR22" check to $72 \%$ at $1 \mathrm{~kg}$ whereas the decrease in "IR36" was from $42 \%$ in the check to $12 \%$ at $0.5 \mathrm{~kg}$. In "IR28" all insecticide rates and the check were free of RTV. 
Grain yield was about $4 \mathrm{t} / \mathrm{ha}$ in all "IR28" treatments (Fig. 3D). Yield increased from 1.7 $\mathrm{t} / \mathrm{ha}$ in the "IR36" check to $2.7 \mathrm{t} / \mathrm{ha}$ at the 1.0-kg rate. Grain yield in "IR22" increased from $1.5 \mathrm{t} / \mathrm{ha}$ in the check to $2.2 \mathrm{t} / \mathrm{ha}$ at the $1 \mathrm{~kg}$ (AI) insecticide/ ha rate.

Gross profit was highest in "IR28," ranging from $\$ 552$ to $\$ 593$ per hectare. Gross profit was intermediate in "IR36" and lowest in most treatments of "IR22" (Table 3). Gross profit of "IR22" and "IR36" increased significantly from 0 to $1 \mathrm{~kg}$ (AI) carbofuran per hectare; however, the increase in net gain was not significant. The highest gain from insecticide was in the "IR36" treatments and lowest in "IR28." Highest benefit:cost ratios for insecticide were the $0.25-$ and $0.50-\mathrm{kg}$ rates on "IR36." Because of the higher level of N. virescens resistance and low RTV infection in "IR28," there was no yield increase due to insecticide application, and the benefit:cost ratio was low at the lower rates and 1 at the two highest rates.

Table 3. Benefit:cost analysis of varying levels of host plant resistance as affected by rates of soilincorporated carbofuran, Victoria, Laguna, 1984 dry season

\begin{tabular}{|c|c|c|c|c|c|c|}
\hline $\begin{array}{l}\text { Carbofuran } \\
\text { (kg [AI]/ha) }\end{array}$ & $\begin{array}{l}\text { Grain yield } \\
(\mathrm{t} / \mathrm{ha})\end{array}$ & $\begin{array}{l}\text { Gross profitc } \\
(\mathrm{US} \$ / \mathrm{ha})^{\mathrm{a}}\end{array}$ & $\begin{array}{c}\text { Insecticide } \\
\text { application } \\
(\mathrm{US} \$ / \mathrm{ha})^{\mathrm{b}}\end{array}$ & $\begin{array}{l}\text { Net gain } \\
\text { (US\$/ha) }\end{array}$ & $\begin{array}{l}\text { Gain from } \\
\text { insecticide }^{f} \\
(\mathrm{US} \$ / \mathrm{ha})^{\mathrm{d}}\end{array}$ & $\begin{array}{l}\text { Benefit:cost } \\
\text { ratio }^{\text {e }}\end{array}$ \\
\hline \multicolumn{7}{|l|}{ "IR22" } \\
\hline 0.0 & $1.47 \mathrm{~b}$ & $217 b(b)$ & 0 & $217 a$ & - & - \\
\hline 0.25 & $1.75 \mathrm{ab}$ & $258 \mathrm{ab}(\mathrm{b})$ & 8 & $250 a$ & 33 & 4.1 \\
\hline 0.5 & $1.77 \mathrm{ab}$ & $261 \mathrm{ab}(\mathrm{c})$ & 16 & $245 a$ & 28 & 1.8 \\
\hline 0.75 & $2.00 \mathrm{ab}$ & $294 a b(b)$ & 24 & $270 a$ & 53 & 2.2 \\
\hline 1.0 & $2.15 a$ & $317 a(b)$ & 32 & $285 a$ & 68 & 2.1 \\
\hline \multicolumn{7}{|l|}{ "IR36" } \\
\hline 0.0 & $1.68 \mathrm{~b}$ & $248 b(b)$ & 0 & $248 b$ & - & - \\
\hline 0.25 & $2.23 a$ & $328 \mathrm{a}(\mathrm{b})$ & 8 & $320 \mathrm{ab}$ & 72 & 9.0 \\
\hline 0.5 & $2.49 a$ & $367 a(b)$ & 16 & $351 a$ & 103 & 6.4 \\
\hline 0.75 & $2.46 a$ & $363 a(b)$ & 24 & $339 a$ & 91 & 3.8 \\
\hline 1.0 & $2.68 \mathrm{a}$ & $349 a(b)$ & 32 & $362 a$ & 114 & 3.6 \\
\hline \multicolumn{7}{|l|}{ "IR28" } \\
\hline 0.0 & $3.75 a$ & $552 a(a)$ & 0 & $552 a$ & - & - \\
\hline 0.25 & $3.90 \mathrm{a}$ & $575 a(a)$ & 8 & $574 a$ & 22 & 2.8 \\
\hline 0.5 & $4.02 \mathrm{a}$ & $593 a(a)$ & 16 & $577 a$ & 25 & 1.6 \\
\hline 0.75 & $3.84 a$ & $563 a(a)$ & 24 & $541 a$ & -11 & $<1$ \\
\hline 1.0 & $3.79 a$ & $559 a(a)$ & 32 & $527 a$ & -25 & $<1$ \\
\hline
\end{tabular}

In a column, means followed by a common letter within each cultivar and among cultivars with the same rate (in parentheses for gross profit) are not significantly different $(P>0.05$; Duncan's [1951] multiple range test).

a. Based on a rough price of US $\$ 157 / \mathrm{t}$. Exchange rate $=14$ Philippine pesos/US $\$ 1$.

b. Carbofuran (Furadan 3G) at US\$12.12 per $16.7 \mathrm{~kg}$ per bag and labor cost per hectare of US $\$ 2$ per $8 \mathrm{~h}$ for broadcasting granules.

c. Gross profit - cost of insecticide application.

d. Net gain of treatment - net gain of control.

e. Gain from insecticide $\div$ cost of insecticide application. 


\section{Discussion}

In locations where RTV is endemic, it is necessary to grow cultivars having high levels of resistance to $N$. virescens. Although the insecticides were more effective in moderately resistant "IR36" than in susceptible "IR22," the protection of each cultivar was not economically acceptable. The net gain was highest on resistant "IR28." If more effective and cheaper insecticides were available, the economics of treating moderately resistant cultivars would be more attractive.

Among the commercially available insecticides, our experience indicates that few, if any, can control RTV infection when vector pressure is high. However, more effective insecticides may be found in the future, and these may increase the profitability of insecticide use on susceptible cultivars.

The results of this study indicated that the best control of RTV infection occurs when a $N$. virescens-resistant cultivar is grown and insecticides are not used. Profits are high, the cost of the insecticide would not be lost if the crop were destroyed by a typhoon, and humans or the natural enemies are not exposed to toxic chemicals.

Cultivars that have genetic resistance to RTV in addition to resistance to the vector must be developed. When resistant cultivars are grown over wide areas, selection pressure may result in the selection of $N$. virescens biotypes that are virulent on the previously resistant cultivars. With RTV resistance, RTV infection would remain low in those situations.

\section{References Cited}

Duncan, D. B. 1951. A significance test for differences between ranked treatments in an analysis of variance. Va. J. Sci. 2: 171-189.

Heinrichs, E. A., F. G. Medrano, L. Sunio, H. Rapusas, A. Romena, C. Vega, V. Viajante, D. Centina, and I. Domingo. 1982. Resistance of IR varieties to insect pests. Int. Rice Res. Newsl. 7(3): 9-10.

IRRI (International Rice Research Institute). 1984. Annual report for 1983. Los Banos, Philippines.

Lamey, H. A., P. Surin, S. Disthaporn, and L. Wathanakul. 1967. The epiphytotic of yellow orange leaf disease of rice in 1966 in Thailand. FAO Plant Prot. Bull. 15(4): 67-69.

Ling, K. C. 1975. Rice virus diseases. International Rice Research Institute, Los Banos, Philippines.

Ling, K. C., and M. K. Palomar. 1966. Studies on rice plants infected with the tungro virus at different ages. Philip. Agric. 50: 165-177.

Rapusas, H. R., and E. A. Heinrichs. 1982. Plant age and levels of resistance to green leafhopper, Nephotettix virescens (Distant), and tungro virus in rice varieties. Crop Prot. 1: 91-98. 